\title{
ЗМІНИ ФУНКЦІОНАЛЬНОГО СТАНУ ПРООКСИДАНТНОЇ ТА АНТИОКСИДАНТНОЇ СИСТЕМ У НАДНИРКОВИХ ЗАЛОЗАХ МОРСЬКИХ СВИНОК ЗА УМОВ ФОРМУВАННЯ ЕКСПЕРИМЕНТАЛЬНОГО АЛЕРГІЧНОГО АЛЬВЕОЛІТУ
}

Вступ. Важливу роль для розуміння патогенезу алергічного альвеоліту відіграють процеси пероксидного окиснення ліпідів та антиоксидантної системи. За фрізіологічних умов рівень пероксидного окиснення ліпідів підтримується завдяки рівновазі про- й антиоксидантної систем. Пероксидне окиснення ліпідів розглядають як універсальний механізм пошкодження клітини на мембранному рівні при різних патологічних станах. Зокрема, гіпоксія, запалення, стрес, алергія активізують процеси ліпопероксидації та пригнічують як фрерментативну, так і нефрерментативну ланки антиоксидантного захисту. Продукти ліпопероксидації негативно впливають на мембрани клітин і проявляють безпосередню пошкоджувальну дію на тканину надниркової залози.

Мета дослідження - оцінити вплив процесів пероксидного окиснення ліпідів і стану антиоксидантної системи в надниркових залозах за умов формування експериментального алергічного альвеоліту.

Методи дослідження. Досліди було проведено на 36 морських свинках масою тіла 0,18-0,20 ке. їх поділили на чотири групи (n=9): 1-ша - інтактні (контроль); 2-га, 3-тя і 4-та - тварини з експериментальним алергічним альвеолітом, відповідно, на 1-шу, 2-гу, 34-ту доби експерименту. Експериментальний алергічний альвеоліт відтворювали за методом О. О. Орєхова, Ю. А. Кирилова. Активність каталази досліджували за методом R. Holmes, C. Masters, супероксиддисмутази - за методом R. Fried, вміст дієнових кон'югатів - за методом В. Б. Гаврилова, М. І. Мішкорудної, рівень малонового діальдегіду - за методом Е. Н. Коробейникової. Статистичне опрацювання - стандартне.

Результати й обговорення. Як показали результати наших досліджень, активність фрерментів антиоксидантної системи змінювалась однонаправлено залежно від періодів фрормування експериментального алергічного альвеоліту. Спостерігали підвищення активності продуктів пероксидного окиснення ліпідів, як початкового, так і завершального його етапів. Водночас активність окремих фрерментів антиоксидантної системи зазнала протилежних змін.

Висновки. Отримані результати свідчать про значні зміни стану про- й антиоксидантної систем у тимусі тварин з експериментальним алергічним альвеолітом та є важливими для кращого розуміння його патогенезу. Дані дослідження дають можливість здійснити пошук більш ефективних і результативних способів корекції виявлених змін при експериментальному алергічному альвеоліті.

КЛЮЧОВІ СЛОВА: експериментальний алергічний альвеоліт; надниркові залози; прооксидантна система; антиоксидантна система.

ВСТУП. Проблема діагностики, лікування та патогенезу експериментального алергічного альвеоліту (EAА) за останні роки набула особливої актуальності та важливого соціально-економічного значення. Це захворювання може перебігати під маскою багатьох хвороб бронхолегеневого апарату (туберкульозу, бронхіту, бронхіальної астми, грипу, саркоїдозу легень), тому (с) М. Є. Ковальська, 2017. виникають різноманітні труднощі в процесі верифікації діагнозу [1, 2].

Сьогодні вже відомі етіологічні чинники ЕАA, проте не повністю з'ясовано механізми його розвитку, зокрема роль та значення процесів пероксидного окиснення ліпідів і стану антиоксидантної системи (AOC) у патогенезі цього захворювання. Невивченим залишається питання, яке стосується впливу вмісту в надниркових залозах 
дієнових кон'югатів (ДК) і малонового діальдегіду (МДА) й активності фрерментів АОС - супероксиддисмутази (СОД) і каталази (КТ) за умов формування експериментального алергічного альвеоліту.

Мета дослідження - оцінити вплив процесів пероксидного окиснення ліпідів і стану антиоксидантної системи в надниркових залозах за умов фрормування експериментального алергічного альвеоліту.

МЕТОДИ ДОСЛІДЖЕННЯ. Досліди на тваринах виконували 3 дотриманням ухвали Першого національного конгресу з біоетики про захист хребетних тварин, які використовуються для експериментальних та наукових цілей $[3,4]$.

Комісія з біоетики Львівського національного медичного університету імені Данила Галицького порушень морально-етичних норм при проведенні науково-дослідної роботи не виявила.

Експериментальні дослідження виконували на кафедрі патологічної фрізіології Львівського національного медичного університету імені Данила Галицького.

Досліди було проведено на 36 морських свинках масою тіла 0,18-0,20 кг. Їх поділили на чотири групи (по дев'ять тварин у кожній): 1-ша інтактні (контроль); 2-га, 3-тя і 4-та - тварини 3 ЕАА, відповідно, на 1-шу, 2-гу, 34-ту доби експерименту. Тести, які відображають процеси прооксидантної (ДК, МДА) та антиоксидантної (СОД, КТ) систем у надниркових залозах, проводили інтактним морським свинкам і тваринам з ЕАA.

Ранній період - 1-ша і 2-га доби ЕАА від початку введення антигену. Пізній період-34-та доба ЕАА від початку введення антигену.

Експериментальний алергічний альвеоліт відтворювали за методом О. О. Орєхова, Ю. А. Кирилова [5].

Тварин декапітували під ефірним наркозом на 1-шу, 2-гу, 34-ту доби експерименту. Проводили забір тканини надниркової залози, з якої готували гомогенат.

Активність каталази в гомогенаті досліджували за методом R. Holmes, C. Masters [6], супероксиддисмутази - за методом R. Fried [7], вміст дієнових кон'югатів - за методом В. Б. Гаврилова, М. І. Мішкорудної [8], рівень малонового діальдегіду - за методом Е. Н. Коробейникової [9].

Статистичне опрацювання цифрових даних проводили з використанням загальноприйнятого методу Стьюдента. Статистично достовірними вважали результати, при яких $p \leq 0,05$.

РЕЗУЛЬТАТИ Й ОБГОВОРЕННЯ. 3 МЕТОЮ вивчення особливостей функціонального стану про-й антиоксидантної систем у морських свинок в різні періоди розвитку ЕАА визначали ДК, МДА, СОД і КТ у тканині надниркової залози.

У результаті проведених досліджень було виявлено, що на 1-шу, 2-гу і 34-ту доби розвитку EAA в надниркових залозах морських свинок поступово зростала інтенсивність утворення продуктів пероксидного окиснення ліпідів.

Так, вміст ДК та МДА зріс у надниркових залозах морських свинок на 1-шу добу, відповідно, на 19,61 \% $(p<0,05)$ і 21,09 \% $(p<0,05)$ порівняно $з$ контролем, тоді як на 2-гу добу показники дещо знизились - відповідно, на 6,41 \% $(p<0,05)$ та $12,35 \%(p<0,05)$ порівняно з величинами інтактних тварин. Тоді як вміст ДК та МДА на 34-ту добу експерименту збільшився, відповідно, на $109,74 \%(p<0,05)$ та 97,22\% $(p<0,05)$ порівняно з інтактними тваринами, що вказує на активізацію пероксидації ліпідів.

Активність КТ у надниркових залозах підвищувалась у ранній період ЕАА (1-ша і 2-га доби), відповідно, на 18,91 та 13,05 \%, у пізній (34-та доба) - на 45,24 \%, а активність СОД зростала на 1-шу, 2-гу і 34-ту доби, відповідно, на 10,56, 8,51 та 29,34 \% порівняно з величинами інтактних морських свинок $(p<0,05)$.

Як показали результати наших досліджень, активність ферментів АОС змінювалась однонаправлено залежно від періодів формування EAA.

У морських свинок з ЕАА спостерігали підвищення активності продуктів пероксидного окиснення ліпідів, як початкового, так і завершального його етапів. Рівень ДК у надниркових залозах зростав на 1-шу, 2-гу і 34-ту доби, відповідно, на 19,61, 6,41 та 109,74 \%, рівень МДА в надниркових залозах збільшувався на ці ж доби, відповідно, на 21,09, 12,35 і 97,22 \% порівняно $з$ контролем, що свідчить про активізацію процесів пероксидного окиснення ліпідів.

Водночас активність окремих ферментів АОС зазнала протилежних змін. Показники СОД і КТ знизились на 2-гу добу, відповідно, на 8,51 та 13,05 \% проти показників контрольної групи тварин, що вказує на пригнічення ферментативної ланки антиоксидантного захисту за умов формування алергічного альвеоліту.

ВИСНОВКИ. Отримані результати свідчать про значні зміни стану про- й антиоксидантної систем у тимусі тварин з експериментальним алергічним альвеолітом та $€$ важливими для кращого розуміння його патогенезу. Дані дослідження дають можливість здійснити пошук більш ефективних і результативних способів корекції виявлених змін при експериментальному алергічному альвеоліті. 


\section{СПИСОК ЛІТЕРАТУРИ}

1. Екзогенний алергічний альвеоліт / М. С. Регеда, Р. Ю. Грицко, Л. А. Любінець. - Львів : Сполом, 2007. $200 \mathrm{c}$.

2. Екзогенний алергічний альвеоліт : монограсрія / [М. С. Регеда, Р. Ю. Грицко, І. Г. Гайдучок та ін.]. - 2-ге вид., доповн. і переробл. - Львів : Сполом, 2007. $201 \mathrm{c}$.

3. Положення про Комітет з питань етики (біоетики) [Електронний ресурс] : наказ Міністерства освіти і науки, молоді та спорту України від 19.11.2012 р. № 1287. - Режим доступу : http://www.mon.gov.ua/ua/ activity/63/64/normativno-pravova-baza/.

4. Біоетична експертиза доклінічних та інших наукових досліджень, що виконуються на тваринах : метод. рек. / О. Г. Резніков, А. І. Соловйов, Н.В.Добреля, О. В. Стефранов // Вісн. фрармакології та фрармаціï. - 2007. - № 7. - С. 47-61.

5. Орехов О. О. Патоморфология легких и микроциркуляторного русла малого круга кровообращения при хроническом экспериментальном аллергическом альвеолите / О. О. Орехов, Ю. А. Кирилов // Арх. патологии. - 1985. - № 10. - С. 54-61.

6. Holmes R. Epigenetic interconversions of the multiple forms of mouse liver catalase / R. Holmes, C. Masters // FEBS Lett. - 1970. - 11, No. 1. - P. 45-48.

7. Fried R. Enzymatic and non-enzymatic assay of super oxide dismutase // Biochemie. - 1975. - 57, 65. P. 657-660.

8. Гаврилов В. Б. Спектрофотометрическое определение содержания гидроперекисей липидов в плазме крови / В. Б. Гаврилов, М.И.Мишкорудная // Лабораторная диагностика ишемической болезни сердца. - К. : Здоров'я, 1989. - С. 170-171.

9. Коробейникова Э. Н. Модификация определения продуктов ПОЛ в реакции с тиобарбитуровой кислотой / Э. Н. Коробейникова // Лаб. дело. - 1989. № 7. - C. 8-10.

\section{REFERENSES}

1. Reheda, M.S., Hrytsko, R.Yu., \& Liubinets, L.A. (2007). Ekzohennyi alerhichnyi alveolit [Exogenous allergic alveolitis]. Lviv: Spolom [in Ukrainian].

2. Reheda, M.S., Hrytsko, R.Yu. \& Haiduchok, I.H. (2007). Ekzohennyi alerhichnyi alveolit: monohrafiia (2-he vydannia, dopovnene i pereroblene) [Exogenous allergic alveolitis: monograph (2nd edition, supplemented and redone)] [in Ukrainian].

3. Polozhennia pro Komitet z pytan etyky (bioetyky) [Regulations on the Ethics Committee (Bioethics)]. (Normatyvnyi dokument Ministerstva osvity, nauky, molodi ta sportu Ukrainy. Nakaz vid 19.11.2012 № 1287): Normatyvno-pravova baza Ministerstva osvity i nauky Ukrainy (ofitsiinyi veb-sait) -(Normative Document of the Ministry of Education, Science, Youth and Sports of Ukraine, Order No. 1287 dated November 19, 2012): Regulatory and Legal Framework of the Ministry of Education and Science of Ukraine (official website). Retrieved from: http://www.mon.gov.ua/ua/activity/63/64/normativno-pravova-bazal.

4. Reznikov, O.H., Soloviov, A.I., Dobrelia, N.V. \& Stefanov, O.V. (2007). Bioetychna ekspertyza doklinichnykh ta inshykh naukovykh doslidzhen, shcho vykonuiutsia na tvarynakh (metodychni rekomendatsii) [Bioethical examination of preclinical and other scientific researches performed on animals (methodical recommendations)].
Visnyk farmakolohii ta farmatsii- Journal of Pharmacology and Pharmacy, 7, 47-61 [in Ukrainian].

5. Orekhov, O.O. \& Kirilov, Yu.A. (1985). Patomorfologiya legkikh i mikrotsirkulyatornogo rusla malogo kruga krovoobrashcheniya pri khronicheskom eksperimentalnom allergicheskom alveolite [Pathomorphology of the lungs and microcirculatory bed of the small circle of circulation in chronic experimental allergic alveolitis]. Arkhiv patologii - Archive of Pathology, 10, 54-61 [in Russian].

6. Holmes, R. \& Masters, C. (1970). Epigenetic interconversions of the multiple forms of mouse liver catalase. FEBS Lett., 11 (1), 45-48.

7. Fried, R. (1975). Enzymatic and non-enzymatic assay of super oxide dismutase. Biochemie, 57 (65), 657-660.

8. Gavrilov, V.B. \& Mishkorudnaya, M.I. (1989). Spektrofotometricheskoye opredeleniye soderzhaniya gidroperekisey lipidov $v$ plazme krovi. Laboratornaya diagnostika ishemicheskoy bolezni serdtsa [Spectrophotometric determination of the content of lipid hydroperoxides in blood plasma. Laboratory diagnostics of coronary heart disease]. Kyiv: Zdorovia [in Ukrainian].

9. Korobeynikova, E.N. (1989). Modifikatsiya opredeleniya produktov POL $v$ reaktsii $s$ tiobarbiturovoy kislotoy [Modification of the definition of LPO products in a reaction with thiobarbituric acid]. Laboratornoye delo Laboratory Case, 7, 8-10 [in Russian]. 


\section{ИЗМЕНЕНИЯ ФУНКЦИОНАЛЬНОГО СОСТОЯНИЯ ПРООКСИДАНТНОЙ И АНТИОКСИДАНТНОЙ СИСТЕМ В НАДПОЧЕЧНИКАХ МОРСКИХ СВИНОК В УСЛОВИЯХ ФОРМИРОВАНИЯ ЭКСПЕРИМЕНТАЛЬНОГО АЛЛЕРГИЧЕСКОГО АЛЬВЕОЛИТА}

\section{Резюме}

Вступление. Важную роль для понимания патогенеза аллергического альвеолита играют процессы перекисного окисления липидов и антиоксидантной системы. В фризиологических условиях уровень перекисного окисления липидов поддерживается благодаря равновесию про- и антиоксидантной систем. Перекисное окисление липидов рассматривают как универсальный механизм повреждения клетки на мембранном уровне при различных патологических состояниях. В частности, гипоксия, воспаление, стресс, аллергия активизируют процессы липопероксидации и подавляют как фрерментативное, так и нефрерментативное звенья антиоксидантной защиты. Продукты липопероксидации негативно влияют на мембраны клеток и проявляют непосредственное повреждающее действие на ткань надпочечника.

Цель исследования - оценить влияние процессов перекисного окисления липидов и состояния антиоксидантной системы в надпочечниках в условиях фрормирования экспериментального аллергического альвеолита.

Методы исследования. Опыты были проведены на 36 морских свинках массой тела 0,18-0,20 ка. Их разделили на четыре группы (n=9): 1-я - интактные (контроль); 2-я, 3-я, 4-я - животные с экспериментальным аллергическим альвеолитом, соответственно, на 1-е, 2-е, 34-е сутки исследования. Экспериментальный аллергический альвеолит воспроизводили по методу О. О. Орехова, Ю. А. Кирилова. Активность каталазы исследовали по методу R. Holmes, C. Masters, супероксиддисмутазы - по методу R. Fried, содержание диеновых конъюгатов - по методу В. Б. Гаврилова, М. И. Мишкорудной, уровень малонового диальдегида - по методу Э. Н. Коробейниковой. Статистическая обработка -стандартная.

Результаты и обсуждение. Как показали результаты наших исследований, активность ферментов антиоксидантной системы изменялась однонаправленно в зависимости от периодов фрормирования экспериментального аллергического альвеолита. Наблюдали повышение активности продуктов перекисного окисления липидов, как начального, так и завершающего его этапов. В то же время активность отдельных фрерментов антиоксидантной системы претерпела противоположных изменений.

Выводы. Полученные результаты свидетельствуют о значительных изменениях состояния про- $u$ антиоксидантной систем в тимусе животных с экспериментальным аллергическим альвеолитом и важны для лучшего понимания его патогенеза. Данные исследования дают возможность осуществить поиск более эфффективных и результативных способов коррекции выявленных изменений при экспериментальном аллергическом альвеолите.

КЛЮЧЕВЫЕ СЛОВА: экспериментальный аллергический альвеолит; надпочечники; прооксидантная система; антиоксидантная система.

\section{CHANGES OF THE FUNCTIONAL STATE OF THE PROOXIDATIVE AND ANTIOXIDANT SYSTEMS IN SURFACES OF THE SEA PIGS IN THE CONDITIONS OF FORMATION OF EXPERIMENTAL ALLERGEN ALVEOLITIS}

\section{Summary}

Introduction. Important role in understanding the pathogenesis of allergic alveolitis is played by processes of lipid peroxidation (LPO) and antioxidant system (AOS). Under physiological conditions, the level of $L P O$ is maintained due to the equilibrium of pro- and antioxidant systems. LPO is considered as a universal mechanism of cell damage 
at the membrane level in conditions of different pathological conditions. In particular, hypoxia, inflammation, stress, allergy activate lipoperoxidation processes and suppress both an enzymatic and non-enzymatic activity of antioxidant defense. Products of lipoperoxidation negatively affect cell membranes and have a direct damaging effect on the adrenal gland tissue.

The aim of the study - to evaluate the influence of lipid peroxidation processes and the state of the antioxidant system in the adrenal glands in the conditions of the formation of experimental allergic alveolitis.

Research Methods. The experiments were conducted on 36 guinea pigs, body weight $0.18-0.20 \mathrm{~kg}$. They were divided into four groups $(n=9)$. Intact - the first group (control). Animals with experimental allergic alveolitis, respectively, on the $1^{\text {st }}, 2^{\text {nd }}$, and $34^{\text {th }}$ day of the experiment. Experimental allergic alveolitis was modeled by O. O. Oriekhov, Yu. A. Kyrylov method. Activity of catalase was studied by B.Holmes, C. Masters method; superoxide dismutase - by R. Fried method; diene conjugates - by V. B. Havrylov, M. I. Mishkorudna method; malonic dialdehyde by $E$. N. Korobeinikov method. Statistical processing is standard.

Results and Discussion. The results of our studies revealed that the activity of the antioxidant system enzymes varied unidirectionally, depending on the periods of formation of the experimental allergic alveolitis. There is an increase in lipid peroxidation products both in its initial and final stages. At the same time, the activity of individual enzymes of antioxidant system underwent opposite changes.

Conclusions. The obtained results indicate significant changes in the state of pro- and antioxidant systems in the thymus of animals with experimental allergic alveolitis and are important for a better understanding of the pathogenesis of experimental allergic alveolitis. These studies provide an opportunity to find more effective and useful ways to correct the detected changes in experimental allergic alveolitis.

KEY WORDS: exogenous allergic alveolitis; adrenal glands; prooxidant system; antioxidant system.

Отримано 03.10.17

Адреса для листування: М. Є. Ковальська, Львівський національний медичний університет імені Данила Галицького, вул. Пекарська, 69, Львів, 79010, Україна, e-mail: cms.meduniv.gmail.com. 